\title{
Understanding the purpose of benefit corporations: an empirical study on the Italian case
}

\author{
Giorgio Mion ${ }^{1 *}$ (D) and Cristian R. Loza Adaui ${ }^{2}$ (D)
}

\begin{abstract}
Rethinking the traditional understanding of organizational purpose appears to be necessary. A teleological paradigm shift seems to be on its way, changing the focus of attention from considering business organizations as instruments used to generate profits toward a more comprehensive understanding of their purpose and of the benefit they can create for society. Recently, new organizational entities have emerged, accompanied by the renewal of institutional frameworks, among them are benefit corporations. Italy was the first European country to introduce a legal framework to define the benefit corporation as a particular legal entity. The Italian law on the benefit corporations proposes the promotion of firms that pursue the generation of benefit in a responsible, sustainable, and transparent way and considering diverse stakeholders. This paper explores and describes the multidimensional understanding of benefit and purpose of Italian benefit corporations, utilizing qualitative and quantitative content analysis of 94 Italian benefit corporations' purpose declarations, and providing a deep insight into the purpose declared by benefit corporations. The research highlights a certain vagueness in public declarations of the purpose of benefit corporations, even though it is clear that they attempt to differentiate themselves from traditional businesses by focusing on social objectives more than on economic ones. Furthermore, normative compliance emerged, but further normative requirements seem to be needed to make more effective the transformative potentiality of benefit corporations and to avoid risks of opportunistic behaviors.
\end{abstract}

Keywords: Benefit corporations, Purpose of the firm, Organizational purpose, Purpose-driven organizations

\section{Introduction}

Business organizations have seen their power rapidly increase during the twentieth century, not only about hegemony in economic and financial resources but also concerning their social and political role. This role offers the opportunity for business organizations to contribute to solving global economic and socioenvironmental issues. Over the past decades, dominant research narratives have employed a monocausal approach to examining the organizational purpose (e.g., Jensen, 2002). This singleobjective in the context of businesses has been often

\footnotetext{
* Correspondence: giorgio.mion@univr.it

${ }^{1}$ Department of Business Administration, University of Verona, via Cantarane, 24, 37129 Verona, Italy

Full list of author information is available at the end of the article
}

identified as profit creation that favors shareholders, without the assumption of any other responsibility except complying with relevant laws (Friedman, 1970).

The single-objective perspective has been criticized as reductionist (Koslowski, 2000, 2001; Naughton, Alford, \& Brady, 1995; Stout, 2012), and it has been more intensively contested in the aftermath of the financial crisis, which started in 2008 (e.g., Moore, 2012; Stiglitz, 2010) and generated a profound decline of public trust in business organizations. Thus, the need to rethink the univocal manner in which organizational purpose has been traditionally understood has become more pressing. A teleological paradigm shift seems to be on its way, and it is changing the focus of attention from a single-objective approach that considers business organizations as mere instruments used

\section{Springer Open}

(๑) The Author(s). 2020 Open Access This article is licensed under a Creative Commons Attribution 4.0 International License, which permits use, sharing, adaptation, distribution and reproduction in any medium or format, as long as you give appropriate credit to the original author(s) and the source, provide a link to the Creative Commons licence, and indicate if changes were made. The images or other third party material in this article are included in the article's Creative Commons licence, unless indicated otherwise in a credit line to the material. If material is not included in the article's Creative Commons licence and your intended use is not permitted by statutory regulation or exceeds the permitted use, you will need to obtain permission directly from the copyright holder. To view a copy of this licence, visit http://creativecommons.org/licenses/by/4.0/. 
to generate profits, toward a multiple-objective approach that embraces a comprehensive understanding of the organizational purpose and the benefit business organizations can create for society (Loza Adaui \& Mion, 2016; Pies, Schreck, \& Hoffmann, 2018; Stubbs \& Cocklin, 2008).

There is no standard definition of organizational purpose, and scholars provided different notions. In detail, some authors described the purpose as the motive of being of an organization or the reason for its creation (e.g., Hollensbe, Wookey, Hickey, George, \& Nichols, 2014; Pascarella \& Frohman, 1989; Reyes \& Kleiner, 1990; Warriner, 1965). Other scholars choose a definition of organizational purpose that emphasizes the role of the purpose beyond other business goals, first all the profit (Basu, 1999; Henderson \& Van den Steen, 2015; Hurth, 2017).

The increasing awareness of long-term sustainability issues in society (e.g., climate change, increasing social inequality) and a more interconnected global civil society have become the drivers of renewed attention to rethinking business' organizational purposes (EY Beacon Institute, 2016), as demonstrated by empirical observations (Harvard Business Review Analytics Services, 2015).

Despite the dominant paradigm of profit maintaining its pervasiveness as the principal goal of firms, new organizational entities that emphasize the role of organizational purpose have emerged, including benefit corporations (BCs). After the emergence of $\mathrm{BCs}$ in the United States (US), a broad diffusion of new regulatory arrangements occurred in several states of the US. In Europe, Italy was the first European country to introduce a legal framework that defines a $\mathrm{BC}$ as a particular legal entity and to formally regulate some aspects of the existence of this type of corporation. Italian Law 28-122015 n. $208 \$ 376-384$, which came into force toward January 2016, proposed the promotion of firms that pursue the generation of benefit in a responsible, sustainable, and transparent manner that considers diverse stakeholders, such as employees, customers, suppliers, and civil society. Even though there is an established Italian tradition about social-oriented organizations, the newly introduced legal framework for BCs (in Italian, "società benefit") calls for a new step of evolution of business organizations and their purpose.

Given that Italian law is generic in terms of the purpose of $\mathrm{BCs}$, and empirical evidence about the organizational purpose of $\mathrm{BCs}$ is still scarce, this paper aims to provide empirical evidence and contribute to the debate by exploring the organizational purpose of Italian BCs. The paper adopts a qualitative research design and applies a content analysis to the public declaration of 94 Italian BCs. In detail, the research question is twofold: first, what is the declared purpose of Italian BCs?, and second, how do Italian BCs declare the operationalization of their benefit goals in terms of benefit creation and delivery to stakeholders?
The remainder of this paper proceeds as follows. The following section addresses the literature on the purpose of the firm and the research on BCs, first at a global level and then in the particular case of Italy. Then, we describe the research methodology and present the characteristics of the analyzed sample of Italian BCs. In the subsequent section, we present and discuss the results. Finally, we present conclusions and propose further research.

\section{Literature review}

\section{The development of benefit corporations as purpose- driven organizations}

The relevance of the discussion of organizational purpose is reinforced by the existence of organizational entities that reveal a combined (or complex) purpose and that are labeled in different ways such as social enterprises (Borzaga \& Defourny, 2001; Elkington \& Hartigan, 2008; Mair, Battilana, \& Cardenas, 2012) or hybrid organizations (Battilana \& Dorado, 2010; Battilana, Lee, Walker, \& Dorsey, 2012; Haigh \& Hoffman, 2012).

These new business entities are often identified as "purpose-driven" or "purposeful" in contrast to the market-driven organizations and emphasizing their blended mission (Bull \& Ridley-Duff, 2019). Indeed the term "purpose" assumes a specific connotation that not only identifies that a firm has a clear mission that can be expressed merely as profit-seeking (Quinn \& Thakor, 2018), but that it also explicitly adopts a blended mission that combines economic, social, and environmental goals (Muñoz, Cacciotti, \& Cohen, 2018).

One challenge faced by these organizations is the choice of a legal status that fit to their blended purpose. In some cases, these organizations develop independently from a specific institutional framework, while in other cases, new regulations have been introduced to foster the development of these new organizations and to safeguard stakeholders from possible greenwashing practices (Stecker, 2016). Indeed, in many countries, there are efforts to develop legal frameworks that are capable of embracing the complexity of new organizational entities that are oriented toward blended ends such as BCs (André, 2015; Hiller, 2013; Robson, 2015) or low-profit limited-liability companies (L3Cs) (Artz, Gramlich, \& Porter, 2012; Lang \& Minnigh, 2010; Tyler, 2010), the latter with lower success (Callison \& Vestal, 2010). As empirically observed by Cooney, Koushyar, Lee, and Murray (2014), several years after the promulgation of legislation for new organizational entities in many states of the US, an increasing number of companies is choosing to operate under these two new legal forms, with very rapid growth in the number of BCs. 
As Robson (2015, p. 521) reports, BCs represent a legal form that was legislated in most of the states of the US. The legislation for BCs introduces a series of innovations, one of them directly relating to the purpose of organizations and their governance. According to Robson (2015), the purpose of a BC extends beyond the maximization of shareholder benefits toward the creation of public benefit, understood as a "material positive impact on society and the environment, taken as a whole, [and] assessed against a third party standard" (p. 522).

From this perspective, it becomes clear that a favorable institutional framework is required to encourage and enable the development of purpose-driven organizations. Currently, legislation for BCs has been passed in more than half the states of the US, and outside the US, there is legislation in Puerto Rico and Italy.

The introduction of the legal form of BCs was forestalled by the Benefit Corporation Movement, which was triggered by B Lab in the US in 2006 (Roth \& Winkler, 2018, p. 14). According to Roth and Winkler (2018), the role of the B Lab was critical in the creation of the following three initiatives that had the goal of providing the "needed infrastructure and support" (p. 14) to develop organizations with a purpose: first, building a community of companies certified as "B Corps"; second, creating a legal infrastructure; and third, developing and providing a global rating system called the "Global Impact Investing Rating System".

The most substantial amount of literature focuses on the societal arrangements realized to promote the existence of BCs, for example, changes in regulatory frameworks or the creation of new laws (for reviews, see Cao, Gehman, \& Grimes, 2017; Grimes, Gehman, \& Cao, 2018). Gehman, Grimes, and Cao (2019) identified 226 academic articles and book chapters on BCs published in the past 10 years (2009-2018), and 137 of these are devoted to the legal aspects of BCs.

Further, research has explored the social role played by BCs at a macro-level by examining areas such as the implications of BCs' movement for public policy (Vaughan \& Arsneault, 2018); the role of BCs in promoting a circular economy (Poponi, Colantoni, Cividino, \& Mosconi, 2019); and the role of $\mathrm{BCs}$ in introducing more significant social commitment in critical economic sectors such as the pharmaceutical industry (e.g., Eiser \& Field, 2016; Frood, 2017). BCs have also been recognized as a factor that can drive change in the economic system from the perspective of conceptual innovation (Wolf, 2018).

Nonetheless, there is an entire stream of research focused on the organizational and managerial levels of BCs. For example, from a theoretical perspective, Sabeti (2011) presents the primary and secondary characteristics of BCs. Further, Gehman and Grimes (2017) examine the particularities of belonging to this category of organization and the reasons why some organizations will (or will not) take the opportunity to promote their membership in this category of organization. At this same level of analysis, at least three studies are connecting BCs to corporate social responsibility (André, 2012; Hiller, 2013; Winkler, Brown, \& Finegold, 2019). André (2012) suggests that BCs allow the implementation of corporate social responsibility more effectively, and this output can be considered partially confirmed by Winkler et al. (2019), who explicitly addressed the role of employee ownership and employee involvement in BCs, finding that mainly employee ownership contributes to external-stakeholder engagement.

Perhaps one of the more extended groups of literature related to $\mathrm{BCs}$ is the research examining $\mathrm{BCs}$ in connection with sustainable entrepreneurship (Stubbs, 2017a). The novelty of this category of organizations has been researched from the perspective of considering these organizations hybrid organizations (Baudot, Dillard, \& Pencle, 2020; Rawhouser, Cummings, \& Crane, 2015; Stubbs, 2017a, 2017b) and as social enterprises (Hemphill \& Cullari, 2014; Kimbrell, 2013; Murray, 2012). Given that the number of $\mathrm{BCs}$ and social enterprises continues to grow, research providing an in-depth understanding of the motivation that compels entrepreneurs to choose these new forms of business and to commit their firms to a blended purpose emerged and grew faster.

Another crucial literature stream concerns BCs' business model that was presented as a possible way to renew the dominant business models, as in the case of Hawaii (Rawhouser et al., 2015). In this line, Sabeti (2011) identified a possible fourth-sector business model based on the integration of economic, social, and environmental goals. Wilburn and Wilburn (2014) defined this business model as the "double bottom line." Despite this optimistic view, previous literature is not unanimous about the existence of a $\mathrm{BCs}$ ' business model. While some studies faced this issue successfully referring to BCorps, the need for further research persists about BCs. Stubbs studied Australian B-Corps' business model and detected it as the response to the need for a new sustainable business model (Stubbs, 2017a, 2019), capable of integrating economic and social objectives with environmental concerns. On the contrary, Nigri and Del Baldo (2018) focused the business model of Italian BCs and identified three different approaches.

Based on institutional theory, Cetindamar (2018) performed an analysis of US BCs' level of compliance with the law and highlighted that a large portion of the sample did not declare its commitment to public benefit and did not publish a report on social impact. Collins and Kahn (2016) found that the US model of BCs and the related notion of public benefit are affected by the US's 
neoliberal political rationality. Empirical evidence from other countries could be useful to better understanding whether the purpose of BCs means they have a different business model from traditional corporations founded on a shareholders' perspective. O'Toole (2019) is skeptical about the reality of entrepreneurs' benefit commitment and describes entrepreneurs as a "bit too selfcongratulatory in [their] habit of [crowing] about their do-goodism and commitment to 'make the world a better place"' (p. 81). In contrast, Clark and Babson (2012) and Smith and Rönnegard (2016) interpret BCs as a regulatory attempt to overcome narrow shareholders' perspectives on organizational purpose. Furthermore, in an attempt to define the purpose of BCs, Jonsen (2016) focused on the need to operationalize their organizational purpose as a benefit or common good to reduce the conflict between business owners' expectations and their social commitment.

In any case, the organizational purpose of $\mathrm{BCs}$ is not univocal and requires a more profound understanding that overtakes the perspective of compliance with legal requirements and focuses on the organizational purpose of BCs.

\section{Purpose-driven organizations and benefit corporations in Italy}

The organizational purpose was traditionally an essential issue for Italian managerial studies that pertain to "Economia Aziendale". Several authors contributed to highlighting the blended objectives of businesses that cannot be reduced to profit-making. Since the birth of the Economia Aziendale, businesses were understood as instruments of satisfaction of multiple human needs, not limited to economic ones (Azzini, 1982; Masini, 1968; Onida, 1954; Zappa, 1927, 1957). Under this perspective, the organizational purpose is blended because businesses - even though they assume a for-profit form - also aim to contribute to social development, by sharing value with different stakeholders.

The debate about organizational objectives enlarged during the XX century and focused on the role of businesses in society and the contribution that firms give to the common good (Corticelli, 1995). Catturi (1971) defined the organizational purpose by adopting a tridimensional approach: a business systematically combines an economic, societal, and political role, and its purpose cannot be reduced to profit-seeking (Catturi, 1971 p. 1820). Coda (1986) focused business strategy as a combined action on economic, social, and competitive perspectives: business cannot reach success without integrating social concerns into its purpose, but it cannot contribute to social development without pursuing economic goals. In this line, Molteni (2004) introduced the notion of "sintesi sociocompetitiva" (socio- competitive synthesis) that contributes to define the organizational purpose as a combination of different but not divergent- economic, social, and environmental goals.

Furthermore, a large body of literature about cooperative forms of business (e.g. Lipari, 1989; Matacena, 1990; Tessitore, 1968; Vermiglio, 1990; Zan, 1990), based on the important experiences of cooperatives developed during the XX century in Italy. Italian cooperatives born from different idealistic origins, such as the Catholic Social Teaching and the socialist ideal- expanded their activities on the markets by maintaining various objectives, not limited to profit-making, also because their legal status sharply restricts profit distribution. Also the largely spread experience of social cooperatives -that operate in specific social and educational industries, but do not distribute profits- contributed to enlarge the attention to social business in Italy during the last three decades (Broglia, Corsi, Farinon, \& Mion, 2017; Lionzo, 2002; Thomas, 2004; Travaglini, 1997).

In summary, Italian Economia Aziendale already offered a broad vision of organizational purpose from a long time ago, even though not all businesses can be considered as purpose-driven, and scholars are now defining this notion.

Under the institutional perspective, Italian business law did not offer specific legal forms to purpose-driven organizations out of the nonprofit sector. Apart from the cooperative form, two specific legal forms were developed: social cooperative (Law 8-11-1991 n. 381) and social enterprise (Legislative Decree 24-03-2006 n. 155). Even though both these institutional forms allow operating into the markets, they established the complete prohibition to distribute profits to shareholders and classified themselves as actual nonprofit organizations.

On the contrary, the $\mathrm{BC}$ (società benefit in Italian) is a juridical form introduced in Italy by Law 28-12-2015 n. 208 art. 1 \$\$376-384; Italy was the first European country to regulate formally some aspects of BCs lives, and similar legislative initiatives are developing in other European countries, e.g., in Belgium, Luxemburg, and France (Dutheil, 2019).

As openly declared by Italian law, the policy of the Italian Government and the clear commitment of the Italian Parliament is to proliferate sustainable behavior in all industrial sectors.

The $\mathrm{BC}$ is a legal model that firms can adopt when they are first established, or at any time by changing their statute or constitutive act. Firms that want to become BCs in Italy have to provide a determination of a specific benefit impact in their corporate objective. The Italian law proposes a definition of "benefit" - beneficio comune in Italian - that is wide and rather vague, similar to the definition in US legislations. 
By adopting the legal status of $\mathrm{BC}$, in Italy firms do not obtain any fiscal or financial advantage, so we can consider this adoption as a voluntary choice that is motivated by nonfinancial aims such as the desire to create social benefit, acquire reputational advantage, or demonstrate an ethical approach to conducting business. The Italian law assigns managers the responsibility for the pursuit of benefit as declared in the statute of the corporations.

Similar to what has occurred in research in the context of the US, Italian researchers have generally focused the juridical aspects of the legal form of BC (e.g., Bertarini, 2016; Corso, 2016; Palmieri, 2017; Riolfo, 2019; Siclari, 2016; Ventura, 1996) and the aspects of policy related to the new legislation on BCs (e.g., Testi, Bellucci, Franchi, \& Biggeri, 2017; Venturi \& Rago, 2015). There is a lack of empirical evidence on the institutional and managerial aspects of Italian BCs, despite some first studies having focused on specific issues such as performance measurement of BCs (Nigri \& Del Baldo, 2018) or the analysis of pioneering cases (Del Baldo, 2019).

There is no public governmental register of $\mathrm{BCs}$ in Italy because this specific juridical status is not a different firm format, but must be associated with one of the traditional forms of corporations such as limited liability companies or cooperatives. Therefore, there are no official data for the number of $\mathrm{BCs}$ founded or transformed during the first 2 years of enforcement of the Law 2812-2015 n. $208 \$ 376-384$. Nonetheless, Italian law introduces some duties about transparency and accountability: on the one hand, BCs have to declare their benefit goals in their statute; on the other hand, they have to publish an annual report that provides evidence of BC's performances about benefit goals.

In June 2018, according to the public and voluntary register managed by Nativa (an Italian Benefit Corporation that is a licensee of B Corp Certification for Italy) to which $\mathrm{BCs}$ can subscribe and provide information, there were $166 \mathrm{BCs}$ in Italy. Besides, at the same time, there were 129 Italian $\mathrm{BCs}$ with available data on the AIDA Bureau van Dijk database.

The most substantial portion of BCs included on the AIDA Bureau van Dijk database are new companies (93 out of the $129 \mathrm{BCs}$ ); these are constituted as limitedliability companies, and very few BCs are constituted as cooperatives.

\section{Research methods \\ Research design}

The present research aims to investigate the understanding of the benefit and purpose of Italian BCs by analyzing how these $\mathrm{BCs}$ publicly declare their mission. Moreover, the research explores how Italian BCs operationalize and communicate their understanding of benefit.
Given that there is no previous empirical evidence relating to the research questions, we adopted a grounded theory approach to content analysis, which is appropriate for investigating an unexplored area (Krippendorff, 2019). The grounded theory approach allowed us to draw out the purpose from a heterogeneous material that BCs published on their websites and Nativa's website.

\section{Sample description and data collection}

We built the sample of analysis by crossing data from two sources and assigning a code to each corporation: the Nativa database and the AIDA Bureau van Dijk database, both consulted on June 4, 2018. The sample counts 98 Italian BCs, 70 of which have a working website and 86 of which have published information about their benefit objectives on the Nativa database. Therefore, we obtained valid information for analysis with 94 cases (Table 1).

Although there are $\mathrm{BCs}$ in almost all Italian regions except Valle d'Aosta, Trentino Alto Adige, Umbria, Molise and Calabria, the distribution is unequal because more than two-thirds of Italy's BCs are located in Northern Italy, the most developed part of the country where the number of firms is higher (Table 2).

Among the 94 analyzed firms, 62 were established as BCs after Law 28-12-2015 n. $208 \$ 376-384$ entered into force, while 32 were transformed from being generic forprofit corporations to being $\mathrm{BCs}$, some of which are long-lived companies. The majority of the $\mathrm{BCs}$ in the sample are organized as limited liability companies (94\%), with only five opting for a cooperative legal structure.

It is also interesting to note that only 17 of these BCs are certified B Corp, which means having demonstrated their benefit orientation by submitting themselves to the judgment of the certification organization and obtaining a satisfactory score on the assessment scale. Few BCs have declared an intention to certify themselves as B Corp, meaning that the vast majority of the sample has adopted only the juridical attributes of BCs, without submitting themselves to an assessment process. Italian $\mathrm{BCs}$ operate in several industrial sectors (e.g., manufacturing, finance, administrative services, healthcare), none of which has prevalent representation among BCs.

\section{Data analysis}

To achieve the research aims, we performed a qualitative content analysis to create an original coding system that emerged during the analysis (Hsieh \& Shannon, 2005). We began the data analysis applying open coding to identify the key themes in the first-order analysis and continued the process of code building by relating categories and subcategories through their properties (axial 
Table 1 Sample of analysis and main characteristics of BCs

\begin{tabular}{|c|c|c|c|c|c|c|}
\hline \multirow[t]{2}{*}{ Code } & \multirow[t]{2}{*}{ Sector (NAICS 2017 description) } & \multirow{2}{*}{$\begin{array}{l}\text { Geographical } \\
\text { area }\end{array}$} & \multirow{2}{*}{$\begin{array}{l}\text { Age } \\
\text { of } B C\end{array}$} & \multirow{2}{*}{$\begin{array}{l}\text { Certified } \\
\text { B-Corp }\end{array}$} & \multicolumn{2}{|c|}{ Source of declaration } \\
\hline & & & & & Nativa database & Website \\
\hline SB003 & Administrative and Support and Waste Management & South \& Isles & 13 & No & 1 & 0 \\
\hline SB004 & Wholesale Trade & North & 2 & No & 1 & 1 \\
\hline SB005 & Manufacturing & North & 6 & No & 1 & 1 \\
\hline SB008 & Manufacturing & Center & 10 & Yes & 1 & 1 \\
\hline SB009 & Real Estate Rental and Leasing & Center & 2 & No & 1 & 0 \\
\hline SB013 & Finance and Insurance & Center & 2 & No & 1 & 0 \\
\hline SB014 & Professional, Scientific, and Technical Services & North & 1 & No & 0 & 1 \\
\hline SB019 & Information & North & 1 & No & 1 & 1 \\
\hline SB020 & Information & North & 1 & No & 1 & 1 \\
\hline SB021 & Manufacturing & South \& Isles & 2 & Yes & 1 & 1 \\
\hline SB023 & Construction & South \& Isles & 7 & No & 0 & 0 \\
\hline SB025 & Agriculture, Forestry, Fishing and Hunting & North & 2 & No & 1 & 1 \\
\hline SB027 & Health Care and Social Assistance & North & 2 & No & 1 & 1 \\
\hline SB030 & Professional, Scientific, and Technical Services & North & 2 & No & 1 & 0 \\
\hline SB031 & Construction & North & 17 & No & 1 & 0 \\
\hline SB032 & Administrative and Support and Waste Management & North & 1 & No & 1 & 0 \\
\hline SB033 & Health Care and Social Assistance & North & 2 & No & 1 & 1 \\
\hline SB034 & Information & Center & 3 & Yes & 1 & 1 \\
\hline SB036 & Wholesale Trade & North & 25 & Yes & 1 & 1 \\
\hline SB037 & Health Care and Social Assistance & South \& Isles & 1 & No & 1 & 0 \\
\hline SB039 & Professional, Scientific, and Technical Services & Center & 17 & No & 1 & 1 \\
\hline SB040 & Manufacturing & North & 1 & No & 1 & 0 \\
\hline SB043 & Wholesale Trade & North & 3 & Yes & 1 & 1 \\
\hline SB044 & Administrative and Support and Waste Management & Center & 3 & No & 1 & 1 \\
\hline SB045 & Administrative and Support and Waste Management & North & 18 & No & 1 & 0 \\
\hline SB046 & Professional, Scientific, and Technical Services & North & 2 & No & 1 & 0 \\
\hline SB047 & Professional, Scientific, and Technical Services & North & 1 & No & 1 & 1 \\
\hline SB049 & Administrative and Support and Waste Management & South \& Isles & 2 & No & 1 & 0 \\
\hline SB050 & Educational Services & South \& Isles & 2 & No & 1 & 0 \\
\hline SB051 & Information & North & 30 & Yes & 1 & 1 \\
\hline SB052 & Wholesale Trade & North & 2 & No & 1 & 1 \\
\hline SB053 & Information & North & 1 & No & 1 & 1 \\
\hline SB055 & Accommodation and Food Services & Center & 18 & No & 1 & 0 \\
\hline SB056 & Administrative and Support and Waste Management & North & 3 & No & 1 & 1 \\
\hline SB057 & Finance and Insurance & North & 2 & No & 1 & 0 \\
\hline SB058 & Utilities & North & 2 & No & 1 & 0 \\
\hline SB059 & Administrative and Support and Waste Management & South \& Isles & 2 & No & 1 & 1 \\
\hline SB060 & Educational Services & North & 1 & No & 0 & 1 \\
\hline SB062 & Professional, Scientific, and Technical Services & Center & 2 & No & 1 & 0 \\
\hline SB063 & Wholesale Trade & North & 2 & No & 1 & 1 \\
\hline SB064 & Wholesale Trade & North & 1 & No & 1 & 0 \\
\hline SB065 & Professional, Scientific, and Technical Services & Center & 6 & Yes & 1 & 0 \\
\hline SB069 & Health Care and Social Assistance & North & 2 & No & 1 & 1 \\
\hline
\end{tabular}


Table 1 Sample of analysis and main characteristics of BCs (Continued)

\begin{tabular}{|c|c|c|c|c|c|c|}
\hline \multirow[t]{2}{*}{ Code } & \multirow[t]{2}{*}{ Sector (NAICS 2017 description) } & \multirow{2}{*}{$\begin{array}{l}\text { Geographical } \\
\text { area }\end{array}$} & \multirow{2}{*}{$\begin{array}{l}\text { Age } \\
\text { of } B C\end{array}$} & \multirow{2}{*}{$\begin{array}{l}\text { Certified } \\
\text { B-Corp }\end{array}$} & \multicolumn{2}{|c|}{ Source of declaration } \\
\hline & & & & & Nativa database & Website \\
\hline SB071 & Health Care and Social Assistance & North & 2 & No & 1 & 0 \\
\hline SB073 & Professional, Scientific, and Technical Services & North & 2 & No & 1 & 0 \\
\hline SB074 & Real Estate Rental and Leasing & North & 1 & No & 1 & 0 \\
\hline SB081 & Wholesale Trade & North & 8 & Yes & 1 & 1 \\
\hline SB082 & Professional, Scientific, and Technical Services & North & 2 & No & 0 & 0 \\
\hline SB083 & Professional, Scientific, and Technical Services & North & 2 & No & 0 & 1 \\
\hline SB089 & Real Estate Rental and Leasing & North & 3 & No & 0 & 0 \\
\hline SB090 & Professional, Scientific, and Technical Services & North & 18 & No & 0 & 0 \\
\hline SB093 & Educational Services & Center & 14 & Yes & 1 & 1 \\
\hline SB096 & Health Care and Social Assistance & Center & 2 & No & 1 & 1 \\
\hline SB097 & Professional, Scientific, and Technical Services & South \& Isles & 5 & No & 1 & 1 \\
\hline SB098 & Manufacturing & North & 5 & Yes & 1 & 0 \\
\hline SB099 & Other Services (except Public Administration) & North & 1 & No & 1 & 1 \\
\hline SB100 & Health Care and Social Assistance & South \& Isles & 2 & No & 1 & 0 \\
\hline SB102 & Manufacturing & South \& Isles & 2 & No & 1 & 1 \\
\hline SB104 & Professional, Scientific, and Technical Services & North & 16 & Yes & 1 & 0 \\
\hline SB105 & Real Estate Rental and Leasing & North & 1 & No & 1 & 0 \\
\hline SB107 & Professional, Scientific, and Technical Services & North & 6 & Yes & 1 & 1 \\
\hline SB110 & Utilities & Center & 4 & Yes & 1 & 1 \\
\hline SB111 & Professional, Scientific, and Technical Services & North & 1 & No & 1 & 0 \\
\hline SB112 & Professional, Scientific, and Technical Services & Center & 2 & No & 1 & 0 \\
\hline SB113 & Accommodation and Food Services & South \& Isles & 2 & No & 1 & 0 \\
\hline SB116 & Accommodation and Food Services & North & 46 & Yes & 1 & 0 \\
\hline SB117 & Educational Services & Center & 1 & No & 0 & 0 \\
\hline SB119 & Administrative and Support and Waste Management & North & 2 & No & 1 & 0 \\
\hline SB121 & Wholesale Trade & North & 2 & No & 1 & 1 \\
\hline SB123 & Accommodation and Food Services & South \& Isles & 2 & No & 1 & 0 \\
\hline SB124 & Administrative and Support and Waste Management & North & 2 & No & 1 & 0 \\
\hline SB125 & Wholesale Trade & North & 2 & No & 1 & 0 \\
\hline SB126 & Real Estate Rental and Leasing & South \& Isles & 1 & No & 1 & 0 \\
\hline SB127 & Health Care and Social Assistance & North & 2 & Yes & 1 & 0 \\
\hline SB128 & Professional, Scientific, and Technical Services & North & 2 & No & 1 & 1 \\
\hline SB130 & Professional, Scientific, and Technical Services & North & 2 & No & 1 & 1 \\
\hline SB132 & Wholesale Trade & North & 3 & No & 0 & 0 \\
\hline SB133 & Administrative and Support and Waste Management & North & 27 & No & 1 & 0 \\
\hline SB135 & Health Care and Social Assistance & Center & 2 & No & 1 & 0 \\
\hline SB136 & Professional, Scientific, and Technical Services & North & 1 & No & 0 & 0 \\
\hline SB138 & Educational Services & Center & 8 & No & 1 & 0 \\
\hline SB139 & Health Care and Social Assistance & Center & 60 & No & 1 & 1 \\
\hline SB140 & Professional, Scientific, and Technical Services & North & 3 & No & 1 & 1 \\
\hline SB141 & Administrative and Support and Waste Management & North & 2 & No & 1 & 1 \\
\hline SB142 & Professional, Scientific, and Technical Services & North & 2 & No & 0 & 0 \\
\hline SB145 & Professional, Scientific, and Technical Services & North & 1 & No & 1 & 1 \\
\hline
\end{tabular}


Table 1 Sample of analysis and main characteristics of BCs (Continued)

\begin{tabular}{|c|c|c|c|c|c|c|}
\hline \multirow[t]{2}{*}{ Code } & \multirow[t]{2}{*}{ Sector (NAICS 2017 description) } & \multirow{2}{*}{$\begin{array}{l}\text { Geographical } \\
\text { area }\end{array}$} & \multirow{2}{*}{$\begin{array}{l}\text { Age } \\
\text { of } B C\end{array}$} & \multirow{2}{*}{$\begin{array}{l}\text { Certified } \\
\text { B-Corp }\end{array}$} & \multicolumn{2}{|c|}{ Source of declaration } \\
\hline & & & & & Nativa database & Website \\
\hline SB148 & Administrative and Support and Waste Management & North & 5 & No & 1 & 1 \\
\hline SB149 & Real Estate Rental and Leasing & North & 8 & No & 0 & 0 \\
\hline SB150 & Accommodation and Food Services & North & 2 & No & 1 & 0 \\
\hline SB151 & Professional, Scientific, and Technical Services & North & 3 & No & 1 & 1 \\
\hline SB152 & Retail Trade & North & 15 & Yes & 1 & 0 \\
\hline SB153 & Administrative and Support and Waste Management & Center & 2 & No & 1 & 0 \\
\hline SB157 & Wholesale Trade & North & 1 & No & 1 & 0 \\
\hline SB160 & Educational Services & Center & 1 & No & 1 & 1 \\
\hline SB161 & Professional, Scientific, and Technical Services & North & 1 & No & 1 & 1 \\
\hline SB162 & Professional, Scientific, and Technical Services & North & 1 & No & 1 & 0 \\
\hline SB163 & Professional, Scientific, and Technical Services & North & 2 & No & 1 & 0 \\
\hline SB166 & Manufacturing & North & 29 & Yes & 1 & 0 \\
\hline
\end{tabular}

coding) (Corbin \& Strauss, 2015) and by identifying the second-order themes and the aggregate dimensions as suggested by Gioia, Corley, and Hamilton (2012). Finally, the selective phase of coding allowed us to form theoretical conclusions.

The content analysis was based on objective hermeneutics, which aims to highlight the deep significance of the text, to avoid the risk of bias caused by the promotional dimension of declaration (Oevermann, Allert, Konau, \& Krambeck, 1979; Reichertz, 2004). The data analysis was conducted over two stages, which were completed by the first author and double-checked by the second author.

The results of the coding construction -presented in Fig. 1- came from the abovementioned protocol of analysis, typical of grounded theory: the categories emerged during the analysis and the coding derived from a recurrent process aimed to identify units of sense and categorized them in main themes and aggregate dimensions.

For the drivers of purpose, based on existing literature (e.g., Jeurissen, 1997), we choose to classify them in three levels (micro/individual, meso/organizational, and macro/ market) to understand the origins of these drivers better.

\section{Findings}

\section{Drivers of purpose}

First, the content analysis recognized the drivers of the purpose of $\mathrm{BCs}$, that is, the motivations that impelled the choice of the firms to become a BC. Several companies (51) do not declare why they chose to become BCs, but quite a large part of them (43) explains the reasons for their choice. Based on the analysis of the purpose descriptions of the $\mathrm{BCs}$, the drivers were categorized into three levels: micro-level (individual), mesolevel (organizational), and macro-level (societal).

At the micro-level, some drivers are primarily connected to individuals inside BCs. Especially the drivers connected to factors like the fulfillment of a personal passion or goal, the practice of their religion or spirituality, and the expression of their ethics and values. For example, SB098 defines the choice to become a BCs as "a nonconformist and visionary choice," while SB047 declares this choice as arising from the desire to create "an innovative startup born from the passion and the dream of ten newly graduated young people." Also, spiritual experiences and particular religious belief can affect the choice to create a $\mathrm{BC}$ or transform a business into a BC, for example, SB019 originates from the Economy of Communion and understands job "as an opportunity for growth not only on the professionally but also in consideration of the spiritual and ethical dimension of working."

At the organizational level, there are drivers relating to the self-comprehension of the organizational community and its consolidated practices. Some BCs refer to their historical heritage as long-lived companies, while others identify their purpose as acknowledged social responsibility. SB102 describes its historical birth as follows: "a

Table 2 Geographical distribution of BCs

\begin{tabular}{llll}
\hline Geographical area & Number of BCs & Percentage of BCs & Percentage of active firms \\
\hline North & 62 & $66 \%$ & $50 \%$ \\
Central & 19 & $20 \%$ & $22 \%$ \\
South \& Isles & 13 & $14 \%$ & $28 \%$ \\
\hline
\end{tabular}




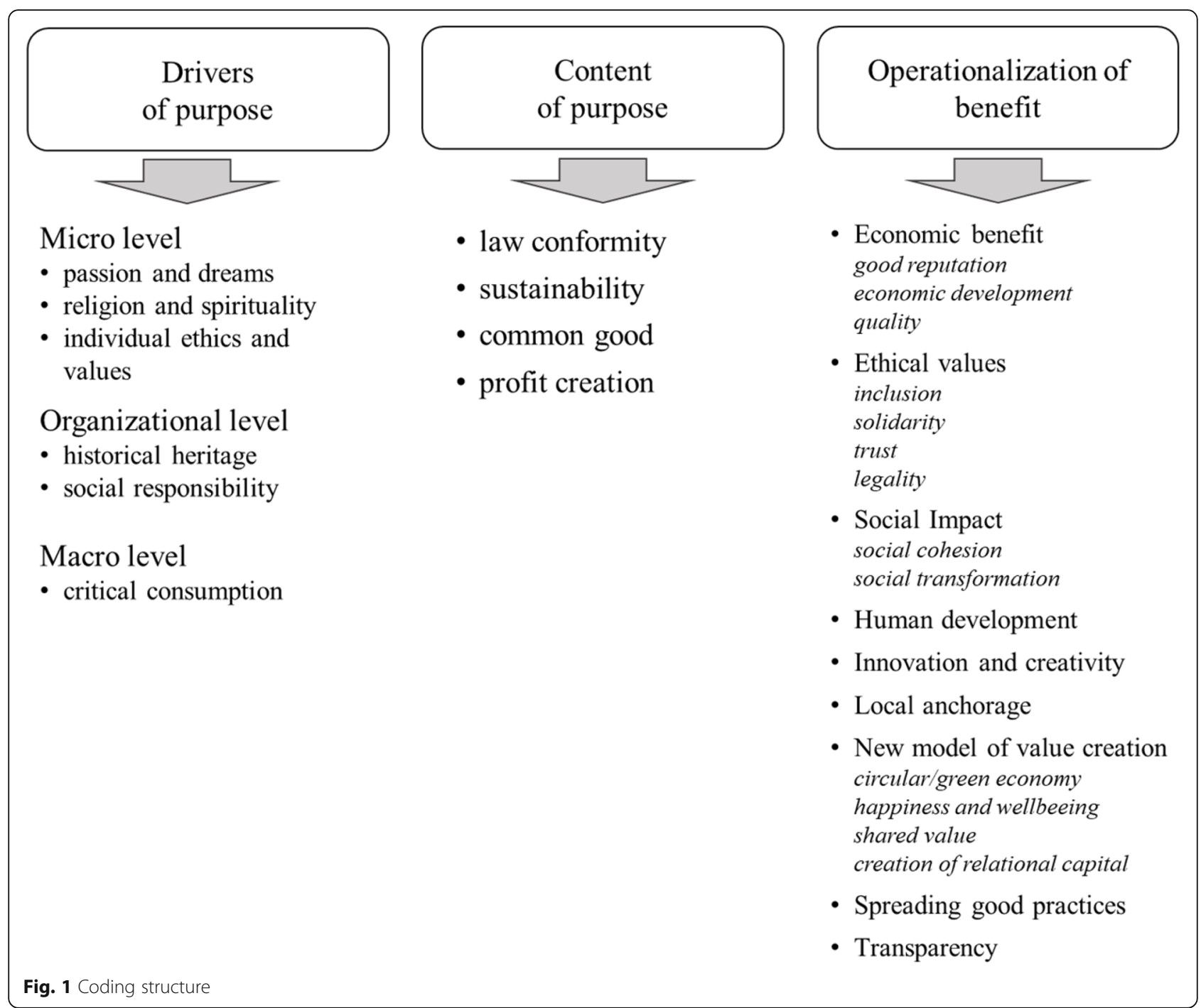

thread that passes across continuous research and heritage of traditions typical of productive microcosms."

It is also possible to identify drivers that have a macrolevel orientation about the organizational benefit, for example, the promotion of critical consumption. SB009 shows its commitment to critical consumption as follows: "sensitizing, spreading and promoting [...] the culture of respect for environmental ecosystems, for the biodiversity of products and cultivations, for the valorization of the territory, for environmental sustainability, for food safety and quality, for recycling and energy saving."

\section{Contents of purpose declarations}

The content analysis of the public declarations of the purpose of Italian BCs produced four categories that describe the content of the purpose declaration: law conformity, sustainability, the common good, and profit creation. However, it should be noted here that none of the previously mentioned categories are exclusive: moreover, the outcome of the analysis demonstrates that the understanding of purpose by $\mathrm{BCs}$ is multidimensional.

In the contents of purpose declarations, one element emerging from the analysis is that many organizations use a reference to the law as part of the purpose declaration, in many cases, even without making an effort to concretize or operationalize how the organizations pursue the benefit. All BCs must be compliant with the law, but some BCs have chosen to limit their declaration to regulatory requirements without explaining the specific understanding they have of "benefit" that has led to them creating the firm as a BC. For example, the SB157 described its mission as follows:

"As a benefit corporation, the firm wants to pursue one or more goals of common benefit and operates in a responsible, sustainable and transparent way towards people, communities, territories and the 
environment, cultural and social assets and activities, organizations and associations and other stakeholders paying particular attention to sustaining pharmaceutical research in spreading and promoting innovative pharmaceutical use that is beneficial to common health."

More than $80 \%$ of this declaration is taken from the law (in italics), and there is only a general reference to the pharmaceutical industry and no information about the expected effect of the firm's activity. Therefore, the real social benefit that can be expected from these corporations' activities remains unclear.

Other BCs declare that sustainability is at the core of their purpose, with a particular focus on the environmental dimension of this broad category. They understand their purpose as a contribution to sustainable development, above all, by making an effort to ensure clean production and to reduce waste according to the logic of the circular economy. For example, SB019, a BC that operates in the chemical industry, declares the following on its purpose declaration: "The commitment carries on to sustainable development, that is, the capacity of people to live decently and fairly, without destroying natural systems from which all people draw the resources necessary to live, and without overcoming the capacity of these natural systems to absorb the waste derived from industrial production."

In some declarations, sustainability is viewed more broadly and vaguely and is matched with other categories such as social responsibility, solidarity, ethics, or welfare. In these cases, it is more challenging to understand whether the $\mathrm{BCs}$ have a clear idea about their purpose, as in the case of SB043, which makes the following general declaration: "We want to operate ethically, integrating sustainable and responsible practices in all our actions."

Other BCs define their purpose about the common good and service of society; in these cases, the companies acknowledge their role as a fundamental part of local and global communities and declare to assume their responsibility through creating shared value. The vocation to the common good is sometimes related to the particular local context, as in the case of SB021, which recognizes the importance of responsible entrepreneurship in a particular territory:

"We want to be an entity and a presence-starting from Southern Italy-that shows the need to come back to a participatory society and not to betray the original purpose of doing business: to fell a healthy part of a complex system, preserving economic independence."
The notion of the common good is broad and is interpreted in different ways by the sample BCs. In some cases, the BCs understand the common good as the capacity of the company to contribute positively to societal change, as in the case of SB047, which declares that "Innovative corporations are bearers of societal improvement, and for this motive, B Corps are proud to have the motto: 'Business as a force of (common) good."

The final purpose encoded in the BCs' declarations is profit creation. Some BCs understand their purpose as ensuring they can create economic value that can contribute to the development of the community. These BCs see profit-making as the best instrument through which a company can reach its economic sustainability and contribute positively to society. This purpose interprets the societal role of businesses in a very traditional manner that does not identify a specific role for BCs, but rather, assumes the same responsibility as any other company.

\section{Operationalizing benefit: creation and delivery}

The content analysis allowed an understanding of how BCs operationalize their purpose about benefit creation and benefit delivery. It is impossible to generalize our findings given the vast differences between many of the sample BCs' declarations, but we were able to come to a general understanding of the transfer of a generalpurpose to concrete managerial action.

Some BCs declare they pursue their mission by creating different forms of economic benefit such as creating a good reputation, improving the quality of products and services, and contributing to economic development.

The promotion of quality is seen as a driver that creates benefits for all people involved in the economic process. For example, SB059 describes its commitment as follows: our company "promotes a European campaign against the mistreatment of laborers in agriculture by supporting the creation of a participatory supply chain of high-quality tomatoes, and building a social alliance between migrant laborers, farmers, consumers, temporary workers, and artists."

$\mathrm{BCs}$ also state the intention to create opportunities for local economic development, above all, if they operate in a critical context such as in poor territories or geographical contexts that limit the development of industrial activities (e.g., SB019 and SB111).

Another way to operationalize benefit is through integrating ethical values into economic practice. In particular, several BCs declare social inclusion as a priority of their corporate activities, sometimes by choosing specific categories of people as beneficiaries of corporate activities (e.g., migrants, poor people, or people with disabilities), sometimes by adopting inclusive commercial politics that allow all types of consumers to access their 
products or services regardless of a personal budget. SB037, which operates in the healthcare sector declares the following: "The company was born from the resolute belief that the concrete and sustainable development of our community need to promote projects and activities that allow as many people as possible access to healthcare and treatments that guarantee the respect of principles of solidarity and human dignity together with efficiency and high service quality."

Other ethical values declared by BCs' as driving their activities are solidarity, trust, and legality. This last value has great importance in local contexts where criminal organizations are powerful and greatly influence social, political, and economic activities. The emphasis on legality is particularly relevant to some of the BCs operating in Southern Italy, where the Mafia has control of many businesses and limits independent and legal initiatives. For these BCs, legality is not only a prerequisite for operation but also a way to create and proliferate benefits. For example, SB141 declares the aim "to promote, enact, and sustain [...] the culture of legality, of transparency towards public administration and community, of protection of rights, and social responsibility".

Our content analysis demonstrated that some BCs operationalize their vocation to benefit creation by generating measurable social effects about social cohesion or social transformation. Sometimes, BCs choose a specific sector of activities such as impact finance for SB005 and SB039 or financial education for SB044, and other $\mathrm{BCs}$ declare a commitment to measuring and assessing their social impact. For example, SB059 declares the following: "The company commits to measuring and to being evaluated on the impact generated by its activity by using an external evaluation standard with characteristics described by the law and choosing as standard the Common Good Balance Sheet standard."

Other BCs operationalize their purpose by pursuing human development or promoting the integrity of the human person as a worker, consumer, and citizen. The importance of human labor is at the center of several BCs' declarations, who understand business as the locus where individuals can improve not only their professional and economic situation, but also improve the relational, emotional, and spiritual dimensions of their lives. For example, SB098 states the following on its website: "To consider the job for the Human Person. The job as an instrument for creating and promoting wellbeing in the biopsychosocial dimension. The job is to elevate human dignity."

Partially related to the issue of human wellbeing is the idea of benefit delivery by local anchorage that promotes the wellbeing of communities. Local anchorage emerged in several $\mathrm{BC}$ declarations, despite there being different nuances of meaning in the use of the term "local anchorage" emerging from the content analysis. Some BCs understand their mission as creating economic opportunities for other businesses in their local context, for example, in the field of agricultural and food specialties or of artisanal products (the so-called "made in Italy"). Other BCs pursue benefit creation and delivery by promoting cultural, social, or political opportunities. SB105 declares that it will achieve its benefit by promoting music and art in its territory, stating that its mission is "to spread and establish roots for the love of music, theater, and dance, understood as forms of artistic and cultural performance, principally among citizens of Ivrea and Canavese." Still, other BCs understand their mission as promoting innovation and creativity. These BCs identify benefits in creating favorable conditions to disseminate innovative ideas and enable individual freedom to express creativity.

Moreover, our content analysis demonstrated that several BCs define their benefit operationalization as a new business model, in line with some contemporary economic trends that involve all types of firms worldwide and are not explicitly related to BCs. Some BCs adopt the model of the circular and green economy as an instrument for creating benefits, for example, by operating in the field of waste recycling and building a sustainable supply chain. Other BCs declare they adopt the managerial approach of "shared value," promoting mutual relations that allow the creation of economic value by sharing voluntary resources and competences. In the Nativa database, SB034 wrote that it "builds local communities of people, encouraging and supporting exchange and sharing of time and talents to create social and economic value and to regenerate human relations."

The creation of relational capital is also another business model chosen by BCs to operationalize their benefit, a goal they aim to reach by promoting happiness and wellbeing among worker communities. In some BCs' declaration, relational capital is not considered a driver of economic value, but an autonomous goal, which by changing job conditions, allows the delivery of the proposed social benefit. For these BCs, value measurement is also centered on happiness, which takes precedence over economic value indicators, for example, SB116 declares that 'Promoting workers' happiness is a key performance indicator, in harmony with celebration and the value of joy represented by the products for the customers."

Some BCs understand their benefit mission as the capacity to spread good practices among markets. In this sense, benefiting the corporation is an objective itself because it allows delivering a model of business in which economic, social, and environmental dimensions are integrated. 
Finally, some of the BCs identify benefit creation with transparency. Identifying benefit as transparency represents a narrow vision of benefit that recognizes the opacity of markets and information asymmetries as the main problems of the contemporary economy and assigns to BCs the role of making markets more transparent. Even if this goal is coherent with a more inclusive and democratic vision of the economy, it is not only related to $\mathrm{BCs}$ but rather includes all businesses in the realization of a positive transformation in corporate culture and economic activity.

\section{Discussion}

The research about $\mathrm{BCs}$ and their purpose seems to be in an early stage, and the findings of our study can contribute to enlarge the discussion. The major contribution of our study is explorative in nature, because it allowed making a first attempt in understanding the content of purpose declaration of Italian BCs and the idea of benefit that these BCs pursue.

BCs formally define themselves as "hybrid organizations" by adopting a legal status that imposes the simultaneous pursuit of different economic, social, and environmental goals. In this sense, our findings confirm a large body of literature that identified BCs as hybrid organizations (e.g., Rawhouser et al., 2015) characterized by a hybrid purpose (Baudot et al., 2020).

Nevertheless, some doubts persist about the effectiveness of formal compliance as a guarantee of BCs' fulfillment to their multidimensional purpose in their practice. While Cetindamar (2018) demonstrated that US BCs do not comply with the law, our study demonstrated that BCs' purpose declarations could be vague despite the BCs complying with the Italian law. This sort of haziness calls for an attentive control on the effectiveness of the benefit objectives of BCs to avoid the risk of greenwashing already highlighted for the US case (Stecker, 2016).

While from a formal perspective, BCs are unambiguously purpose-driven, the findings of our research showed that Italian BCs do not form a homogeneous group in their understanding (and declaration) of specific benefits and purposes, such as Nigri and Del Baldo (2018) highlighted in reference to BCs' business models. There is great diversity among the sampled BCs; thus, it can be concluded that the perception of "benefit" is unclear, and organizational purpose can be understood very differently by different BCs. For example, there are $\mathrm{BCs}$ that define themselves as representing a new business model, but other BCs seem to follow traditional business models that assume corporate social responsibility as the main objective of their strategy. Consequently, our results confirm the findings of previous studies (e.g., Clark \& Babson, 2012; Smith \& Rönnegard,
2016) comparing BCs to traditional firms. Besides, when BCs use widely adopted notions such as "sustainability" to define their purpose, their stated purpose specifically as a BC is unclear, and the boundaries of their social and environmental activities are not clearly defined.

The content analysis demonstrated that some BCs declare no specific purpose but present themselves as being witnesses of a new economic paradigm. In this sense, they do not understand themselves as particular firms, but only as organizations that declare their social and environmental responsibility and can transform markets simply by their presence. This vague narrative seems to confirm the validity of the skeptical approach to BCs expressed by O'Toole (2019) in order of the real capacity of this new form of business to renew the dominant economic paradigms.

However, many BCs in the sample stated their capacity to integrate social and environmental aspects in their mission, alongside value creation, so confirming Stubbs' (2017b) previous findings about B-Corps. Such BCs make a clear effort to define their benefit purpose differently from traditional businesses. The novelty of BCs is sometimes a new type of product or service, or sometimes an alternative model adopted for the internal organization through aspects of business such as human resource management.

BCs understand themselves as change agents, and some of them emphasize the social dimension of their activities. On the contrary, other ones consider crucial reaffirming their vocation to economic value creation. Therefore, some BCs describe themselves more like notfor-profit or third-sector organizations, while others use a narrative that is similar to traditional corporations, even if expressing a clear perception of their social responsibility.

In several of the sampled BCs, the relationship between the purpose and the developed activities was not clear, meaning that for these $\mathrm{BCs}$, the operationalization of benefit is unclear and does not identify a specific way in which the $\mathrm{BC}$ realizes its social vocation. Consequently, it remains unclear if the Italian tradition of Economia Aziendale, is providing fertile ground for the development of BCs beyond their anchorage in the law.

\section{Conclusions}

This paper aimed to enlarge the discussion about the content of the purpose of purpose-driven organizations through an analysis of Italian BCs. Despite the exploratory nature of the study, the contribution of our paper is twofold. First, the paper contributes to filling the gap in empirical evidence about the purpose of Italian BCs. Accordingly, the results of our analysis contribute to the understanding of BCs purpose's contents confirming its multidimensional feature, and implications. Second, the 
paper offers interesting points for reflection on the effects of introducing new legal forms oriented to the support of social entrepreneurs and the role that policymakers can play. The practical implications of the study concern the opportunity to create a clearly defined purpose to avoid reputational risk; this definition can be voluntarily disclosed by each $\mathrm{BC}$ but can also be fostered by more precise legal requirements, and above all, by explicit requirements related to disclosure of purpose and performance.

Our paper has the following three significant limitations: first, the object of the content analysis relates to self-declared information of the companies. Second, the short life history of Italian BCs. Third, it was not possible to compare the declarations of the purpose of certified B Corps with non-certified BCs, because the number of certified B Corps in our sample was too small at the time of sample closure.

Furthermore, to enlarge the observations and support our conclusions, further analysis should be conducted on concrete business practices through which BCs realize their purpose, and practices related to long-term performances and development can be measured.

\section{Abbreviations}

BC: Benefit corporation; CSR: Corporate social responsibility; L3C: Low-profit limited-liability company

\section{Acknowledgments}

Not applicable.

\section{Authors' contributions}

CLA: Introduction, literature review, and theoretical analysis. GM and CLA developed the methodological design conjointly. GM: Data gathering, data analysis, findings, and conclusions. Both authors read and approved the final manuscript.

\section{Funding}

No Authors have received any grants by companies or other organizations.

\section{Availability of data and materials}

The datasets built and analyzed during the current study are available from the corresponding author on reasonable request.

\section{Competing interests}

The authors declare that they have no conflict of interest.

\section{Author details}

'Department of Business Administration, University of Verona, via Cantarane, 24, 37129 Verona, Italy. ${ }^{2}$ Institute of Economics, Friedrich-Alexander University Erlangen-Nürnberg, Kochstr. 4 (17), 91054 Erlangen, Germany.

Received: 1 June 2020 Accepted: 3 August 2020

Published online: 13 August 2020

\section{References}

André, R. (2012). Assessing the accountability of the benefit corporation: Will this new gray sector organization enhance corporate social responsibility? Journal of Business Ethics, 110(1), 133-150. https://doi.org/10.1007/s10551-012-1254-1.

André, R. (2015). Benefit corporations at a crossroads: As lawyers weigh in, companies weigh their options. Business Horizons, 58, 243-252. https://doi. org/10.1016/j.bushor.2014.12.002.
Artz, N., Gramlich, J., \& Porter, T. (2012). Low-profit limited liability companies (L3Cs). Journal of Public Affairs, 12(3), 230-238. https://doi.org/10.1002/pa. 1437.

Azzini, L. (1982). Istituzioni di economia d'azienda. Milano: Giuffrè.

Basu, S. (1999). Corporate purpose: Why it matters more than strategy. New York: Garland Publishing.

Battilana, J., \& Dorado, S. (2010). Building sustainable hybrid organizations: The case of commercial microfinance organizations. Academy of Management Journal, 53(6), 1419-1440. https://doi.org/10.5465/amj.2010.57318391.

Battilana, J., Lee, M., Walker, J., \& Dorsey, C. (2012). In search of the hybrid ideal. Stanford Social Innovation Review, 10(3), 50-55.

Baudot, L., Dillard, J., \& Pencle, N. (2020). The emergence of benefit corporations: A cautionary tale. Critical Perspectives on Accounting, 67, 102073. https://doi. org/10.1016/j.cpa.2019.01.005

Bertarini, B. (2016). La società benefit: Spunti di riflessione sulle nuove prospettive del settore non profit. Diritto e Giustizia, 14, 1-23.

Borzaga, C., \& Defourny, J. (2001). The emergence of social enterprise. London: Routledge.

Broglia, A., Corsi, C., Farinon, P., \& Mion, G. (2017). Tra economicità e bene comune Analisi critica delle cooperative sociali come hybrid organizations. Roma: Rirea.

Bull, M., \& Ridley-Duff, R. (2019). Towards an appreciation of ethics in social Enterprise business models. Journal of Business Ethics, 159(3), 619-634. https://doi.org/10.1007/s10551-018-3794-5.

Callison, J. W., \& Vestal, A. W. (2010). The L3C illusion: Why low-profit limited liability companies will not stimulate socially optimal Private Foundation investment in entrepreneurial ventures. Vermont Law Review, 35(2), 273-293.

Cao, K., Gehman, J., \& Grimes, M. G. (2017). Standing out and fitting in: Charting the emergence of certified B Corporations by industry and region, in A.C. Corbett, \& J. Katz (Eds.), Hybrid Ventures (pp. 1-38) Bingley, UK: Emerald. https://doi.org/10.1108/S1074-754020170000019001.

Catturi, G. (1971). L'impresa come organismo tridimensionale e i suoi obbiettivi alternativi al profitto. Rivista dei Dottori Commercialisti, 6, 1819.

Cetindamar, D. (2018). Designed by law: Purpose, accountability, and transparency at benefit corporations. Cogent Business \& Management, 5(1). https://doi.org/10.1080/23311975.2018.1423787

Clark, W. H. J., \& Babson, E. K. (2012). How benefit corporations are redefining the purpose of business corporation. William Mitchell Law Review, 38(2), 817-851.

Coda, V. (1986). Valori imprenditoriali e successo dell'impresa. In AA.W (Ed.), Valori imprenditoriali e successo aziendale, (pp. 3-38). Milano: Giuffrè.

Collins, J. L., \& Kahn, W. N. (2016). The hijacking of a new corporate form? Benefit corporations and corporate personhood. Economy and Society, 45(3-4), 325349. https://doi.org/10.1080/03085147.2016.1239342.

Cooney, K., Koushyar, J., Lee, M., \& Murray, H. (2014). Benefit corporation and L3C adoption: A survey. In Stanford Social Innovation Review. [Web log post]. Retrieved from https://ssir.org/articles/entry/benefit_corporation_and_I3C_ adoption_a_survey

Corbin, J., \& Strauss, A. (2015). Basics of qualitative research. Techniques and procedures for developing grounded theory, (4th ed., ). Thousand Oaks: Sage Publications. https://doi.org/10.4135/9781452230153.

Corso, S. (2016). Le società benefit nell'ordinamento italiano: Una nuova "qualifica" tra profit e non profit. Le Nuove Leggi Civili Commentate, XXXIX, 5, 995-1031.

Corticelli, R. (1995). L'azienda: Economia e socialità. Rivista Italiana di Ragioneria e di Economia Aziendale, 95(1/2), 24-47.

Del Baldo, M. (2019). Acting as a benefit corporation and a B Corp to responsibly pursue private and public benefits. The case of Paradisi Srl (Italy). International Journal of Corporate Social Responsibility, 4(4), 1-18. https://doi. org/10.1186/s40991-019-0042-y.

Dutheil, P.-H. (2019). Social Enterprises in Europe: The experience of three European countries. Futuribles Journal, 429(2), 55-61. https://doi.org/10.3917/ futur.429.0055.

Eiser, A. R., \& Field, R. I. (2016). Can benefit corporations redeem the pharmaceutical industry? The American Journal of Medicine, 129(7), 651-652. https://doi.org/10.1016/J.AMJMED.2016.02.012.

Elkington, J., \& Hartigan, P. (2008). The power of unreasonable people: How social entrepreneurs create markets that change the world. Boston: Harvard Business Press.

EY Beacon Institute (2016). The state of the debate on purpose in business. Manchester: EY Beacon Institute.

Friedman, M. (1970, September 13). The social responsibility of business is to increase its profits. The New York Times Magazine, p. 12. Retrieved from https://www.nytimes.com/1970/09/13/archives/article-15-no-title.html. 
Frood, A. (2017). Mission control: Drug developers test the "benefit corporation" business model. Nature Medicine, 23(10), 1117-1118. https://doi.org/10.1038/ nm1017-1117.

Gehman, J., \& Grimes, M. (2017). Hidden badge of honour: How contextual distinctiveness affects category promotion among certified B corporations. Academy of Management Journal, 60(6), 2294-2320. https://doi.org/10.5465/ amj.2015.0416.

Gehman, J., Grimes, M. G., \& Cao, K. (2019). Why we care about certified B Corporations: From valuing growth to certifying values practices. Academy of Management Discoveries, 5(1), 97-101. https://doi.org/10.5465/amd.2018.0074.

Gioia, D. A., Corley, K. G., \& Hamilton, A. L. (2012). Seeking qualitative rigor in inductive research: notes on the Gioia methodology. Organizational Research Methods, 16(1), 15-31. https://doi.org/10.1177/1094428112452151.

Grimes, M. G., Gehman, J., \& Cao, K. (2018). Positively deviant: Identity work through B corporation certification. Journal of Business Venturing, 33(2), 130 148. https://doi.org/10.1016/j.jbusvent.2017.12.001

Haigh, N., \& Hoffman, A. J. (2012). Hybrid organizations: The next chapter of sustainable business. Organizational Dynamics, 41, 126-134. https://doi.org/ 10.1016/j.orgdyn.2012.01.006.

Harvard Business Review Analytic Services. (2015). The business case for purpose. Harvard Business School Publishing. Retrieved from https://hbr.org/resources/ pdfs/comm/ey/19392HBRReportEY.pdf.

Hemphill, T. A., \& Cullari, F. (2014). The benefit corporation: Corporate governance and the for-profit social entrepreneur. Business and Society Review. https://doi. org/10.1111/basr.12044.

Henderson, R., \& Van den Steen, E. (2015). Why do firms have "purpose"? The Firm's role as a carrier of identity and reputation. American Economic Review, 105(5), 326-330. https://doi.org/10.1257/aer.p20151072.

Hiller, J. S. (2013). The benefit corporation and corporate social responsibility. Journal of Business Ethics, 118(2), 287-301. https://doi.org/10.1007/s10551012-1580-3.

Hollensbe, E., Wookey, C., Hickey, L., George, G., \& Nichols, C. V. (2014). Organizations with purpose. Academy of Management Journal, 57(5), 12271234. https://doi.org/10.5465/amj.2014.4005.

Hsieh, H.-F., \& Shannon, S. E. (2005). Three approaches to qualitative content analysis. Qualitative Health Research, 15(9), 1277-1288. https://doi.org/10. $1177 / 1049732305276687$.

Hurth, V. (2017). Organizations as open systems that need purpose and integrated thinking. Board Leadership, 2017(150), 1-8. https://doi.org/10.1002/bl.30069.

Jensen, M. C. (2002). Value maximization, stakeholder theory, and the corporate objective function. Business Ethics Quarterly, 12(2), 235-256. https://doi.org/10. 2307/3857812.

Jeurissen, R. (1997). Integrating micro, Meso and macro levels in business ethics. Ethical Perspectives, 4(4), 246-254. https://doi.org/10.2143/ep.4.4.562986.

Jonsen, R. H. (2016). Other-constituency theories and firm governance: Is the benefit corporation sufficient? Journal of Management, Spirituality \& Religion, 13(4), 288-303. https://doi.org/10.1080/14766086.2016.1172250.

Kimbrell, A. R. (2013). Benefit corporation legislation: An opportunity for Kansas to welcome social enterprises. Kansas Law Review, 62, 549-584.

Koslowski, P. (2000). The limits of shareholder value. Journal of Business Ethics, 27(1/2), 137-148. https://doi.org/10.1023/A:1006438000855.

Koslowski, P. (2001). The shareholder value principle and the purpose of the firm. In Y. K. Shionoya (Ed.), Competition, trust, and cooperation, (pp. 179-209). Berlin, Heidelberg: Springer. https://doi.org/10.1007/978-3-642-56836-7_10 .

Krippendorff, K. (2019). Content analysis: An introduction to its methodology. Journal of the American Statistical Association, (4th ed., ). Thousand Oaks: Sage Publications.

Lang, R., \& Minnigh, E. C. (2010). The L3C, history, basic construct, and legal framework. Vermont Law Review, 35(1), 15-30.

Lionzo, A. (2002). La cooperativa sociale. Originalità della formula, economicità e strumenti di analisi. Milano: Franco Angeli.

Lipari, C. (1989). Le forme aziendali cooperative. Principi tematici e sistematici. Milano: Giuffrè.

Loza Adaui, C.R., \& Mion, G. (2016). Catholic social teaching, organizational purpose, and the for-profit/nonprofit dichotomy: Exploring the Metaprofit proposition. Journal of Markets and Morality 19(2), 275-295. Retreived from https://www.marketsandmorality.com/index.php/mandm/article/view/1190/0.

Mair, J., Battilana, J., \& Cardenas, J. (2012). Organizing for society: A typology of social Entrepreneuring models. Journal of Business Ethics, 111(3), 353-373. https://doi.org/10.1007/s10551-012-1414-3.
Masini, C. (1968). Lavoro e risparmio. Corso di economia di azienda. Milano: Succ. Fusi-Pavia.

Matacena, A. (1990). Impresa cooperativa. Obiettivi finalizzanti. Risultati gestionali e bilancio d'esercizio. Bologna: Clueb.

Molteni, M. (2004). Responsabilità sociale e performance d'impresa. Milano: Vita e Pensiero.

Moore, G. (2012). The virtue of governance, the governance of virtue. Business Ethics Quarterly, 22(02), 293-318. https://doi.org/10.5840/beq201222221.

Muñoz, P., Cacciotti, G., \& Cohen, B. (2018). The double-edged sword of purposedriven behavior in sustainable venturing. Journal of Business Venturing, 33(2), 149-178. https://doi.org/10.1016/j.jbusvent.2017.12.005.

Murray, J. H. (2012). Choose your own master: Social Enterprise, certifications, and benefit corporation statutes. American University Business Law Review, 2, 1-42.

Naughton, M. J., Alford, H., \& Brady, B. (1995). The common good and the purpose of the firm: A critique of the shareholder and stakeholder models from the Catholic social tradition. Journal of Human Values, 1(2), 221-237. https://doi.org/10.1177/097168589500100206.

Nigri, G., \& Del Baldo, M. (2018). Sustainability reporting and performance measurement systems: How do small- and medium-sized benefit corporations manage integration? Sustainability, 10(12), 4499-4515. https:// doi.org/10.3390/su10124499.

OToole, J. (2019). The prospects for enlightened corporate leadership. California Management Review, 61(3), 72-92. https://doi.org/10.1177/0008125619839677.

Oevermann, U., Allert, T., Konau, E., \& Krambeck, J. (1979). Die Methodologie einer objektiven Hermeneutik und ihre allgemeine forschungslogische Bedeutung in den Sozialwissenschaften. In Interpretative Verfahren in den Sozial- und Textwissenschaften, (pp. 352-433). https://doi.org/10.1016/j.cviu.2016.06.001.

Onida, P. (1954). L'azienda. Primi principi di gestione e di organizzazione. Milano: Giuffrè.

Palmieri, M. (2017). L'interesse sociale: Dallo shareholder value alle società benefit. Banca Impresa Società, XXXVI, 2, 201-237. https://doi.org/10.1435/87553.

Pascarella, P., \& Frohman, M. A. (1989). The purpose-driven organization: Unleashing the power of direction and commitment. San Francisco: JosseyBass Publishers.

Pies, I., Schreck, P., \& Homann, K. (2018). Reconciling single-objective and multiobjective theories of the firm: A constitutional perspective. Academy of Management Proceedings, 2018(1), 15016. https://doi.org/10.5465/AMBPP. 2018.15016abstract

Poponi, S., Colantoni, A., Cividino, S., \& Mosconi, E. (2019). The stakeholders' perspective within the B Corp certification for a circular approach. Sustainability, 11(6), 1584-1598. https://doi.org/10.3390/su11061584.

Quinn, R. E., \& Thakor, A. V. (2018). Creating a purpose-driven organization. Harvard Business Review, 96(4), 78-85.

Rawhouser, H., Cummings, M., \& Crane, A. (2015). Benefit corporation legislation and the emergence of a social hybrid category. California Management Review, 57(3), 13-36. https://doi.org/10.1525/cmr.2015.57.3.13.

Reichertz, J. (2004). Objective hermeneutics and hermeneutic sociology of knowledge. In U. Flick, E. von Kardoff, \& I. Steinke (Eds.), A companion to qualitative research, (pp. 290-295). London: Sage Publications.

Reyes, J. R., \& Kleiner, B. H. (1990). How to establish an Organisational purpose. Management Decision, 28(7), 51-54. https://doi.org/10.1108/ 00251749010004665.

Riolfo, G. (2019). The new Italian benefit corporation. European Business Organization Law Review. https://doi.org/10.1007/s40804-019-00149-9.

Robson, R. (2015). A new look at benefit corporations: Game theory and game changer. American Business Law Journal, 52(3), 501-555. https://doi.org/10. 1111/ablj.12051.

Roth, F. M. S., \& Winkler, I. (2018). B Corp entrepreneurs. Cham: Springer International Publishing. https://doi.org/10.1007/978-3-319-90167-1.

Sabeti, H. (2011). Spotlight on the good company. The for-benefit Enterprise. Harvard Business Review, 89(11), 1-7.

Siclari, D. (2016). Le società benefit nell'ordinamento italiano. Rivista Trimestrale di Diritto dell'economia, 1, 36-48.

Smith, N. C., \& Rönnegard, D. (2016). Shareholder primacy, corporate social responsibility, and the role of business schools. Journal of Business Ethics, 134(3), 463-478. https://doi.org/10.1007/s10551-014-2427-x.

Stecker, M. J. (2016). Awash in a Sea of Confusion: Benefit Corporations, Social Enterprise, and the Fear of "Greenwashing.". Journal of Economic Issues, 50(2), 373-381. https://doi.org/10.1080/00213624.2016.1176481.

Stiglitz, J. E. (2010). Freefall : Free markets and the sinking of the global economy. London: Penguin. 
Stout, L. A. (2012). The shareholder value myth: How putting shareholders first harms investors, corporations and the public. San Francisco: Berrett-Koehler Publishers.

Stubbs, W. (2017a). Characterising B corps as a sustainable business model: An exploratory study of B corps in Australia. Journal of Cleaner Production, 144, 299-312. https://doi.org/10.1016/j.jclepro.2016.12.093.

Stubbs, W. (2017b). Sustainable entrepreneurship and B corps. Business Strategy and the Environment, 26(3), 331-344. https://doi.org/10.1002/bse.1920.

Stubbs, W. (2019). Strategies, practices, and tensions in managing business model innovation for sustainability: The case of an Australian BCorp. Corporate Social Responsibility and Environmental Management, 26(5), 1063-1072. https://doi. org/10.1002/csr.1786.

Stubbs, W., \& Cocklin, C. (2008). Conceptualizing a "sustainability business model". Organization \& Environment, 21(2), 103-127. https://doi.org/10.1177/ 1086026608318042

Tessitore, A. (1968). I/ concetto di impresa cooperativa in economia d'azienda. Verona: Libreria Editrice Universitaria.

Testi, E., Bellucci, M., Franchi, S., \& Biggeri, M. (2017). Italian social Enterprises at the Crossroads: Their role in the evolution of the welfare state. VOLUNTAS: International Journal of Voluntary and Nonprofit Organizations, 28(6), 24032422 https://doi.org/10.1007/s11266-017-9875-8.

Thomas, A. (2004). The rise of social cooperatives in Italy. VOLUNTAS: International Journal of Voluntary and Nonprofit Organizations, 15(3), 243-263. https://doi. org/10.1023/B:VOLU.0000046280.06580.d8.

Travaglini, C. (1997). Le cooperative sociali tra impresa e solidarietà. Caratteri economico-aziendali ed informativa economico-sociale. Bologna: Clueb.

Tyler, J. (2010). Negating the legal problem of having two masters: A framework for L3C fiduciary duties and accountability. Vermont Law Review, 35(1), 117-161.

Vaughan, S. K., \& Arsneault, S. (2018). The public benefit of benefit corporations. PS: Political Science and Politics, 51(1), 54-60. https://doi.org/10.1017/ S1049096517001391.

Ventura, L. (1996). Contratto e impresa : Europa. Contratto e Impresa, 32(4), 11341167.

Venturi, P., \& Rago, S. (2015). Benefit corporation e impresa sociale: Convergenza e distinzione. Impresa Sociale, 6, 34-36.

Vermiglio, F. (1990). Considerazioni economico-aziendali sull'impresa cooperativa. Natura e caratteri strutturali. Messina: Industria poligrafica della Sicilia.

Warriner, C. K. (1965). The problem of organizational purpose. The Sociological Quarterly, 6(2), 139-146. https://doi.org/10.1111/j.1533-8525.1965.tb01647.x.

Wilburn, K., \& Wilburn, R. (2014). The double bottom line: Profit and social benefit. Business Horizons 57(1), 11-20. https://doi.org/10.1016/j.bushor.2013.10.001.

Winkler, A.-L. P., Brown, J. A., \& Finegold, D. L. (2019). Employees as conduits for effective stakeholder engagement: An example from B corporations. Journal of Business Ethics, 160(4), 913-936. https://doi.org/10.1007/s10551-018-3924-0.

Wolf, J. (2018). The economy effect: Conceptual innovation and benefit corporations. New Political Science, 40(2), 264-284. https://doi.org/10.1080/ 07393148.2018.1449404

Zan, L. (1990). L'economia dellimpresa cooperativa. Torino: Utet.

Zappa, G. (1927). Tendenze nuove negli studi di ragioneria. Milano: Istituto Editoriale Scientifico.

Zappa, G. (1957). Le produzioni nell'economia delle imprese, (vol. I). Milano: Giuffrè.

\section{Publisher's Note}

Springer Nature remains neutral with regard to jurisdictional claims in published maps and institutional affiliations.

\section{Submit your manuscript to a SpringerOpen ${ }^{\circ}$ journal and benefit from:}

- Convenient online submission

- Rigorous peer review

- Open access: articles freely available online

- High visibility within the field

- Retaining the copyright to your article

Submit your next manuscript at $\boldsymbol{\nabla}$ springeropen.com 